\title{
Analisis Kesehatan Koperasi Syariah dalam Upaya Meningkatkan Kinerja dan Pelayanan
}

\author{
${ }^{1}$ Antin Okfitasari, ${ }^{2}$ Agus Suyatno \\ ${ }^{1}$ Manajemen Informatika, STMIK Duta Bangsa, Indonesia \\ ${ }^{2}$ Sistem Informasi, STMIK Duta Bangsa, Indonesia \\ ${ }^{1}$ Email korenpondensi: antin_okfitasari@stmikdb.ac.id
}

Recieved 22-06-2018 | Revised 08-07-2018 | Accepted 23-07-2018

\begin{abstract}
The purpose of research is to analyze the financial health of Savings and Loans Cooperative and Sharia (KSPPS) BMT Mitra Mandiri Wonogiri, Central Java. This research method is quantitative descriptive approach, with sample of KSPPS financial reports from year 2013 until 2016. PermenkopUKM number 7 / Per / Dep.6 / IV /2016, is used as a data analysis tool, which includes capital aspect, quality aspect of productive assets, efficiency aspect, liquidity aspect, and independence aspect and growth aspect. The result based on each health assessment indicator, all indicators indicate healthy category except capital aspect. The financial health assessment of KSPPS BMT Mitra Mandiri from 2013 to 2016 in aggregate and per year show healthy category.
\end{abstract}

Keywords: Sharia Cooperative, The Financial Health Assessment, Permenkop

Saran sitasi: Okfitasari, A., \& Suyatno, A. (2018). Analisis Kesehatan Koperasi Syariah dalam Upaya Meningkatkan Kinerja dan Pelayanan. Jurnal Ilmiah Ekonomi Islam, 4(2), 103-115. doi:http://dx.doi.org/10.29040/jiei.v4i2.260

DOI: http://dx.doi.org/10.29040/jiei.v4i2.260

\section{Pendahuluan}

Koperasi merupakan bentuk usaha yang sesuai dengan perekonomian Bangsa Indonesia yang didasarkan atas usaha bersama berdasarkan asas kekeluargaan. Koperasi sebagai salah satu badan usaha, memerlukan pengelolaan manajemen dan keuangan yang profesional, walaupun berdasar asas kekeluargaan, sehingga mewujudkan koperasi yang handal, profesional dan tetap berprofit untuk kesejahteraan anggota pada khususnya dan perekonomian nasional pada umumnya. Untuk itu perlu bagi koperasi selalu menjaga eksistensinya dengan menjaga kinerja koperasi. Salah satu cara yang dilakukan Kementerian Koperasi dalam mendukung hal ini adalah penilaian kinerja koperasi secara periodik. Hal ini untuk menjamin bahwa semua kegiatan operasional koperasi sesuai jati diri koperasi, sebagai wujud prinsip kehati-hatian. Dengan demikian kepercayaan masyarakat akan meningkatkan kepercayaan dan memberikan manfaat sebesar-besarnya kepada anggota dan masyarakat di sekitarnya (Soedarsa dan Natalia, 2016).

Munculnya Baitul Maal Wa Tamwil (BMT) menjadi tonggak berkembangnya koperasi syariah di Indonesia. Lembaga keuangan mikro di bawah Departemen Koperasi dan UMK ini tidak saja berorientasi bisnis tetapi juga sosial, tidak adanya pemusatan kekayaan pada sebagian kecil pemilik modal (pendiri), tetapi terdistribusi secara adil dan merata kepada seluruh anggota. Hal ini merupakan ciri khas utama dari koperasi syariah, dimana selain mensejahterakan anggotanya, juga memiliki peran sosial di dalam masyarakat terutama mengatasi masalah riba. Untuk mewadahi perkembangan koperasi berba- 
sis simpan pinjam dan pembiayaan syariah, Kemenkop-UKM mengeluarkan Permen nomor 16/Per/M. KUKM/IX/2015 tentang Pelaksanaan Kegiatan Usaha Simpan Pinjam dan Pembiayaan Syariah oleh Koperasi (KSPPS), sebagai aturan pengganti dari Keputusan Menteri Negara Koperasi dan Usaha Kecil dan Menengah Republik Indonesia Nomor: 91/Kep/M.KUKM/IX/2004 mengenai Petunjuk Pelaksanaan Kegiatan Usaha Koperasi Jasa Keuangan Syariah (KJKS). Hal ini sejalan dengan adanya perkembangan dinamika masyarakat yang mengharuskan kesesuaian pelaksanaan koperasi syariah berdasarkan prinsip syariah yang memiliki ciri, bentuk dan sistem tersendiri.

Di dalam Permen nomor 16/Per/M.KUKM/IX/2015 dijelaskan bahwa sebagai lembaga keuangan syariah, usaha simpan pinjam dan pembiayaan syariah oleh koperasi melaksanakan fungsi intermedia yang memiliki ciri, bentuk dan sistem tersendiri harus diatur, diawasi dan dinilai kesehatannya. Penilaian kesehatan perlu dilakukan setiap tahun untuk mengetahui tingkat kesehatan dari segi keuangan, aspek manajemen dan kesesuaian prinsip syariah, Manfaat penilaian kesehatan bagi internal koperasi dapat mengevaluasi kinerja dan prestasi yang sudah dicapai, dan mengevaluasi apakah koperasi dapat berjalan normal. Di sisi eksternal membangun kepercayaan anggota dan masyarakat sekitar untuk dapat memanfaatkan koperasi syariah sebaik mungkin.

Menurut Mulyadi (2001), penilaian kinerja merupakan penentuan efektivitas operasional suatu perusahaan, organisasi, bagian dari organisasi dan karyawannya, yang dilakukan secara periodik sesuai dengan standar, sasaran dan kriteria yang telah ditetapkan. Penilaian kinerja memiliki manfaat bukan hanya sebagai alat monitoring kinerja manajer dan pencapaian tujuan organisasi, tetapi juga memiliki peranan lain yaitu membantu manajer dalam mengawasi posisi strategi perusahaan. Melalui penilaian kinerja, manajemen suatu organisasi dapat mengkomunikasikan bagaimana seharusnya manager berperilaku dan bagaimana perilaku tersebut dinilai dan dievaluasi. Dengan demikian, penilaian kinerja menjadi bagian penting dalam perencanaan dan pengawasan organisasi, karena melalui penilaian kinerja, akan tergambarkan bagaimana pencapaian target suatu organisasi, yang berupa tingkat operasional yang diinginkan maupun laba yang ditetapkan sebelumnya (Hoque, 2003).

Dalam perkoperasian, penilaian kinerja yang dikenal dengan penilaian kesehatan koperasi merupakan sarana untuk mengetahui dan mengukur apakah proses yang ada di dalam operasional dan aktivitas koperasi telah berjalan sesuai dengan standar yang telah ditentukan, berjalan dengan efektif dan efisien (Yusuf, 2016). Dengan demikian, penilaian kesehatan koperasi, merupakan sarana dari Kemenkop sebagai organisasi induk perkoperasian di Indonesia untuk mengawasi dan memastikan kondisi kesehatan koperasi, sehingga memberikan jaminan keamanan dan kepercayaan anggota, mengingat bahwa koperasi merupakan organisasi yang memiliki jatidiri yang berbeda dengan organisasi bisnis lainnya. Hasil penilaian kesehatan diharapkan dapat dipergunakan bagi koperasi yang bersangkutan sebagai pedoman dan bahan pertimbangan pembenahan, perbaikan kinerja koperasi, bahkan sebagai sarana pertimbangan untuk mengubah atau menghentikan operasional koperasi ( Sugiyarso, 2011).

Penelitian terkait dengan analisis kesehatan koperasi syariah telah dilakukan. Kebanyakan penelitian dilakukan menggunakan indiator penilaian kesehatan seperti Perbankan Syariah yaitu Economic Value Added (EVA) (Inayati et al, 2014), PINBUK (Nornita, 2012), CAMEL (Yusuf, 2016, Nurhayadi, 2015), Permenkop nomor 35.3/Per/M.KUKM/X/2007 (Sukmana dan Mulyati, 2015, Afandi, 2014, Sofyan dan Ervina, 2017) dan Permenkop 7/Per/Dep.6/IV/2016 ( Raharjo dan Indriani, 2017). Penelitian yang dilakukan oleh Afandi (2014) dengan KSU BMT Arafah di Semarang dengan menggunakan indikator kinerja keuangan berdasarkan Permenkop-UMM nomor 35.3/Per/M.KUKM/$\mathrm{X} / 2007$. Hasilnya adalah bahwa secara 
pengukuran kesehatan dari indikator permodalan, kualitas aktivitas produktif, efisiensi, likuiditas dan kemandirian dan pertumbuhan menunjukan bahwa selama rentang waktu 2011 sampai dengan 2013 KSU BMT Arafah dinyatakan sehat.

Yusuf (2016) meneliti dengan menganalisis tingkat kesehatan koperasi syariah BMT Al Munawarah. Indikator Penilaian kesehatan koperasi dengan menggunakan CAMEL yang disesuaikan dengan menambah seperti aspek syariah, dengan hasil BMT ini cukup sehat. Penelitian juga dilakukan oleh Nornita (2012), yaitu menganalisis kesehatan pada BMT Bina Ihsanul Fikri dari tahun 2000-2011. Penilaian kesehatan menggunakan metode penilaian kesehatan BMT dari PINBUK. Hasilnya adalah dari aspek jasadiyah dari segi kinerja keuangannya menurut standar pedoman penilaian kesehatan BMT dari PINBUK, BMT Bina Ihsanul Fikri di tahun 2000-2011 mendapatkan predikat kurang sehat.

Raharjo dan Indriani (2017) melakukan penelitian atas penilaian kesehatan pada KSSPS BMT Bina Ummat Mandiri Kota Tegal pada tahun 2013. Indikator penilaian kesehatan menggunakan Permenkop 7/Per/Dep.6/IV/2016. Hasil penelitian menunjukan bahwa secara keseluruhan dari indikator tersebut, KSSPS BMT Bina Ummat Mandiri berpredikat cukup sehat, dengan skor 75,45 .

Terdapat beberapa hal perbedaan Penilaian kesehatan dalam Permenkop nomor 7/Per/Dep.6/IV/2016 dengan Permenkop-UMM nomor 35.3/Per/M.KUKM/X/2007. Perbedaan tersebut adalah komponen penilaian di bagian penilaian aspek efisiensi dan jatidiri koperasi. Perbedaan yang lain dari kedua Permenkop ini adalah katagori hasil penilaian KSPPS, dimana dalam Permenkop baru ini menggunakan istilah dalam pengawasan dan pengawasan khusus, bukan tidak sehat dan kurang sehat. Indikator penilaian yang digunakan dalam penelitian ini adalah penilaian kesehatan yang berhubungan dengan penilaian kinerja keuangan KSPPS.

Penelitian ini berbeda dengan Raharjo dan Indriani (2017), walaupun analisis kesehatan menggunakan indikator yang sama yaitu peni- laian kesehatan sesuai dengan Per nomor 7/Per/Dep.6/IV/2016. Penelitian ini memfokuskan hanya pada indikator penilaian kesehatan yang berhubungan dengan laporan keuangan. Alasannya adalah karena penilaian kinerja dengan memfokuskan pada laporan keuangan yang berupa neraca dan laba rugi memudahkan dalam menganalisa kondisi koperasi dari sisi finansial. Sebagaimana Hoque (2003) menjelaskan bahwa analisis kinerja keuangan merupakan cara untuk yang digunakan untuk mengevaluasi kinerja perusahaan dari dimensi penting yaitu kesehatan dan kelangsungan hidup perusahaan. Perbedaan lain dari penelitian sebelumnya, penelitian menggunakan multi year dan objek penelitian adalah KSPPS BMT Mitra Mandiri Wonogiri.

Objek penelitian yang diteliti adalah KSPPS BMT Mitra Mandiri di Kabupaten Wonogiri. Pemilihan objek penelitian ini berdasar pertimbangan bahwa BMT Mitra Mandiri merupakan salah satu pioner BMT di Wonogiri bahkan di Jawa Tengah. Koperasi Jasa Keuangan Syariah BMT Mitra Mandiri didirikan berdasarkan Badan Hukum nomor 216/BH/KDK.11-29/VII/2004 pada tanggal 12 Juli 2004. Kemudian pada tanggal 11 Januari 2016 berubah menjadi Koperasi Simpan Pinjam dan Pembiayaan Syariah (KSPPS) BMT Mitra Mandiri. KSPPS BMT Mitra Mandiri berkedudukan di Jalan Bima V nomor 03 Wonokarto Wonogiri Jawa Tengah.

Hasil penilaian kesehatan di KSPPS BMT Mitra Mandiri Wonogiri pada tahun 2013 mendapat predikat Sehat dengan skor 82,15. Adapun hasil penilaian kesehatan pada tahun 2014 masih bertahan dengan predikat Sehat, tetapi dengan skor sebesar 81,60. Di tahun 2015, KSPPS BMT Mitra Mandiri mendapat skor sebesar 80,05 dengan predikat Cukup Sehat. Melihat hasil penilaian kesehatan KSPPS BMT Mitra Mandiri tampak bahwa skor tingkat kesehatannya semakin menurun dari tahun 2013 sampai dengan tahun 2015. Hal ini mengakibatkan penurunan "grade" atas katagori kesehatan koperasi. Hal ini tentunya sangat menarik untuk dianalisa untuk mengetahui faktor-faktor penentu apa saja yang 
menyebabkan terjadinya penurunan tingkat kesehatan tersebut. Dengan mengetahui faktorfaktor penentu penyebabnya, maka akan membantu manajemen KSPPS BMT Mitra Mandiri dalam mengambil kebijakan di masa mendatang, guna meningkatkan dan mempertahankan tingkat kesehatan koperasi sebagai indikator keberhasilan kinerja koperasi. Tingkat yang kesehatan koperasi yang stabil tentunya akan memperbaiki pelayanan yang maksimal kepada anggota, yang pada akhirnya menambah kepercayaan anggotanya untuk selalu tetap menanamkan modalnya di dalam koperasi.

Mengingat pentingnya faktor-faktor penentu kesehatan koperasi syariah bagi pihak-pihak yang berkepentingan terhadap posisi keuangan maupun perkembangan koperasi syariah yang telah diuraikan sebelumnya, maka tujuan dari penelitian ini adalah untuk mengetahui tingkat kesehatan KSPPS BMT Mitra Mandiri pada tahun 2013 sampai dengan tahun 2016. Dengan demikian rumusan masalah yang akan dibahas dalam penelitian ini adalah bagaimana tingkat kesehatan KSPPS BMT Mitra Mandiri pada tahun 2013 sampai dengan 2016.

\section{Metode Penelitian}

KSPPS BMT Mitra Mandiri, berkedudukan di Jalan Bima V nomor 03 Wonokarto Wonogiri Jawa Tengah dipilih sebagai objek penelitian. Bentuk penelitian ini adalah deskriptif kuantitatif, dimana suatu penelitian yang ditujukan untuk keadaan, situasi atau hal lain, dan hasil penelitian dipaparkan dalam laporan penelitian (Arikunto, 2013). Sampel yang dipilih adalah laporan keuangan KSPPS BMT Mitra Mandiri dari tahun 2013 sampai dengan 2016. Data yang digunakan adalah data primer dan data sekunder. Data primer dikumpulkan dari wawancara informan, dimana informan yang diwawancarai adalah para manager yang berada di manajemen puncak. Adapun data sekunder dikumpulkan dari laporan keuangan tahun 2013 sampai 2016 yang telah diaudit. Pengumpulan data dilakukan dengan observasi, dokumentasi dan studi pustaka serta informan lainnya.
Teknik analisa yang dilakukan adalah analisa deskriptif kuantitatif. Analisa data dalam mengukur tingkat kesehatan KSPPS berdasarkan Permenkop dan UKM nomor 7/Per/Dep.6/IV/2016 tentang Pedoman Penilaian Kesehatan Koperasi Simpan Pinjam dan Pembiayaan Syariah. Berdasarkan Permenkop tersebut, masingmasing hasil rasio diberi skor dan bobot yang telah ditentukan. Dengan mengalikan hasil rasio dengan skor dan bobot tersebut, selanjutnya dapat ditentukan tingkat kesehatan Koperasi. Penilaian tingkat kesehatan koperasi meliputi aspek:

\section{Permodalan}

Aspek pertama penilaian kesehatan KSPPS adalah permodalan. Penilaian permodalan dilakukan dengan menggunakan dua rasio permodalan yaitu perbandingan modal sendiri dengan asset dan rasio kecukupan modal.

\section{Kualitas Aktiva Produktif}

Penilaian terhadap kualitas aktiva produktif didasarkan pada 3 ( tiga ) rasio, yaitu: rasio tingkat piutang dan pembiayaan bermasalah terhadap jumlah piutang pembiayaan, rasio portofolio terhadap piutang beresiko dan pembiayaan beresiko dan rasio penyisihan penghapusan aktiva produktif (PPAP) terhadap penyisihan penghapusan aktiva produktif yang wajib dibentuk (PPAPWD).

\section{Manajemen}

Manajemen menunjuk pada orang berarti berkaitan dengan para pengelola yang ada dalam organisasi, kaitannya dengan koperasi berarti merujuk pada apa yang sering kita sebut perangkat organisasi koperasi. Menurut UU No.25 Tahun 1992, yang termasuk perangkat organisasi adalah Rapat Anggota, Pengurus dan Pengawas. Penilaian aspek manajemen meliputi beberapa komponen yaitu manajemen umum, kelembagaan, manajemen permodalan, manajemen aktiva, dan manajemen likuiditas.

\section{Efisiensi}

Penilaian efisiensi koperasi didasarkan pada 3 (tiga) rasio yaitu rasio biaya operasional terhadap pelayanan, rasio aktiva tetap terhadap total aset dan rasio efisiensi pelayanan. Rasio- 
rasio di atas menggambarkan sampai seberapa koperasi mampu memberikan pelayanan yang efisien kepada anggotanya dari penggunaan asset yang dimilikinya. Rentabilitas koperasi hanya untuk mengukur keberhasilan perusahaan koperasi yang diperoleh dari penghematan biaya pelayanan.

\section{Likuiditas}

Likuiditas adalah kemampuan jangka pendek, dengan indikator penilaian menggunakan rasio kas dan rasio pembiayaan.

\section{Kemandirian dan Pertumbuhan}

Penilaian terhadap kemandirian dan pertumbuhan didasarkan pada 3 rasio yaitu: rentabilitas asset, rentabilitas ekuitas dan kemandirian operasional.

\section{Jatidiri Koperasi}

Penilaian jatidiri koperasi dimaksudkan untuk mengukur keberhasilan koperasi dalam mencapai tujuannya yaitu mempromosikan ekonomi anggota. Indikator dengan menggunakan dua rasio rasio promosi ekonomi anggota dan rasio partisipasi bruto.

\section{Prinsip Syariah}

Koperasi ini harus memegang prinsip ekonomi Islam yang mengharamkan unsur-unsur aktivitas atau transaksi yang mengandung mysir (judi), gharar (tidak jelas), risywah (suap) dan riba (bunga) atau yang biasa disingkat MAGHRIB. Untuk mengawal gerakan KSPPS agar berjalan sesuai syariah, maka pengurus dan pengelola didampingi dewan pengawas syariah.

Dalam penelitian ini, analisis kesehatam yang digunakan meliputi 5 aspek penilaian yaitu aspek permodalan, aspek kualitas aktiva produktif, aspek efisiensi, aspek likuiditas dan aspek kemandirian dan pertumbuhan. Alasan pemilihan kelima aspek tersebut bahwa kelima aspek tersebut yang paling dekat hubungannya dengan masalah kinerja keuangan. Analisis tingkat kesehatan berdasarkan Permenkop dan UKM nomor 7/Per/Dep.6/IV/2016 yang digunakan dalam penelitian ini dapat dilihat di Tabel 1.

Tabel 1. Analisis Aspek Rasio Permodalan, Kualitas Aktiva Produktif, Efisiensi, Likuiditas, Kemandirian dan Pertumbuhan Dalam Kinerja Keuangan Koperasi

\begin{tabular}{|c|c|c|}
\hline \multirow{2}{*}{ Permodalan } & $\begin{array}{l}\text { a. Rasio modal sendiri terhadap total } \\
\text { asset } \\
\frac{\text { Modal sendiri }}{\text { Total asset }} \times 100 \%\end{array}$ & $\begin{array}{l}3,76-5,00: \text { Sehat } \\
2,51-3,75: \text { Cukup sehat } \\
1,26-2,50: \text { Kurang sehat } \\
0-1,25: \text { Tidak sehat }\end{array}$ \\
\hline & $\begin{array}{l}\text { b. Rasio kecukupan modal (CAR) } \\
\qquad \frac{\text { Modal Tertimbang }}{A T M R} \times 100 \%\end{array}$ & $\begin{array}{l}\text { Rasio } \geq 8 \%=5,00: \text { Sehat } \\
7 \%-<8 \%=3,75: \text { Cukup sehat } \\
6 \%-<7 \%=2,5: \text { Kurang sehat } \\
<6 \%=1,25: \text { Tidak sehat }\end{array}$ \\
\hline \multirow{3}{*}{$\begin{array}{l}\text { Kualitas } \\
\text { Aktiva } \\
\text { Produktif }\end{array}$} & $\begin{array}{l}\text { a. Rasio tingkat pembiayaan dan piutang } \\
\text { bermasalah terhadap jumlah piutang } \\
\text { dan pembiayaan } \\
\frac{\text { Jumlah pembiayaan dan Piutang bermasslah }}{\text { Jumlah piutang dan pembiayaan }} \times 100 \%\end{array}$ & $\begin{array}{l}7,50-10,00: \text { :Lancar } \\
5,00-<7,50: \text { Cukup lancar } \\
2,50-<5,00: \text { Kurang lancar } \\
0-<2,50: \text { Tidak lancar }\end{array}$ \\
\hline & $\begin{array}{l}\text { b. Rasio portofolio pembiayaan beresiko } \\
\frac{\text { Rasio portof olio beresiko }}{\text { Jumlah piutang dan pembiayaan }} \times 100 \%\end{array}$ & $\begin{array}{l}3,75-5,00 \text { :Tidak beresiko } 2,50-<3,75 \\
\text { :Cukup beresiko } \\
1,25-<2,50: \text { Kurang beresiko } \\
0-<1,25: \text { Sangat beresiko }\end{array}$ \\
\hline & $\begin{array}{l}\text { c. Rasio penyisihan penghapusan aktiva } \\
\text { produktif } \\
\qquad \frac{P P A D}{P P A W D} \times 100 \%\end{array}$ & $\begin{array}{l}73,75-5,00: \text { Lancar } \\
2,50-<3,75: \text { Kurang Lancar } \\
1,25-<2,50: \text { Diragukan } \\
0-<1,25: \text { Macet }\end{array}$ \\
\hline Efisiensi & $\begin{array}{l}\text { a. Rasio biaya operasional pelayanan } \\
\text { terhadap partisipasi bruto } \\
\frac{\text { Biaya operasional layanan }}{\text { Partisipasi bruto }} \times 100 \%\end{array}$ & $\begin{array}{l}\text { Rasio }>100 \%=1: \text { Tidak efisien } \\
86 \%-100 \%=2: \text { Kurang efisien } \\
71 \%-85 \%=3: \text { Cukup efisien } \\
<71 \%=4: \text { Efisien }\end{array}$ \\
\hline
\end{tabular}




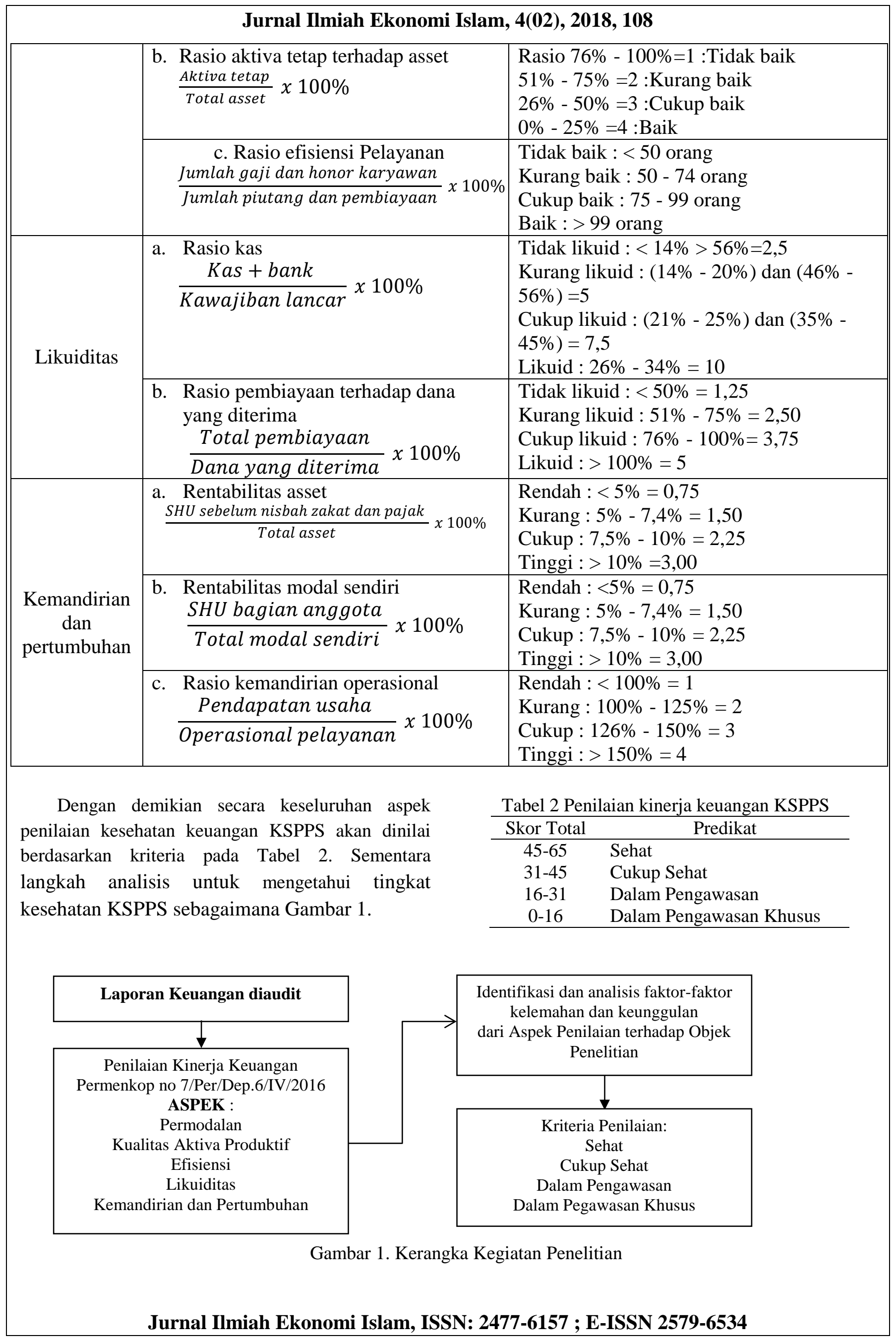




\section{Hasil dan Pembahasan}

\subsection{Hasil Penelitian}

KSPPS BMT Mitra Mandiri Wonogiri adalah suatu koperasi yang berbentuk syariah, yang berdiri pada tanggal 12 Juli 2004, dan sudah memperoleh legalisasi tingkat provinsi sejak tahun 2011. KSPPS BMT Mitra Mandiri berkantor pusat di Jl. Wonogiri - Solo Km.05 Nanggan Gemantar Selogiri Wonogiri, sampai dengan tahun 2016 telah memiliki 13 kantor cabang di Kabupaten Wonogiri.

Hasil analisis penilaian kesehatan KSPPS BMT Mitra Mandiri Wonogiri berdasarkan Permenkop nomor 7/Per/Dep.6/IV/2016 dapat dilihat pada Tabel 3.

\subsection{Pembahasan}

Penilaian Aspek Permodalan

Rasio Modal Sendiri terhadap Total Aset

Berdasarkan analisis yang telah dilakukan, menunjukkan bahwa rata-rata rasio ini dari tahun 2013-2016 mendapat skor 1,25, dengan rasio 5,76\%; $6,86 \% ; 6,61 \% ; 7,50 \%$ secara berurutan. Rasio rerata yang diperoleh sebesar $6,68 \%$ dengan skor rata-rata 1,25 dan merupakan skor terendah. Artinya bahwa KSPPS BMT Mitra Mandiri belum berhasil menumbuhkan keyakinan anggotanya untuk menyimpan dananya di KSPPS. Hasil Penelitian ini sesuai dengan penelitian yang dilakukan oleh Raharjo dan Indriani (2017).

Hasil yang rendah ini kemungkinan juga dipengaruhi oleh penurunan nilai pinjaman jangka

Tabel 3 Hasil Rasio dan Skor Penilaian berdasar Permenkop nomor 7/Per/Dep.6/IV/2016

KSPPS BMT Mitra Mandiri Wonogiri

\begin{tabular}{lcccccccc}
\hline \multirow{2}{*}{ Indikator Penilaian } & \multicolumn{2}{c}{2016} & \multicolumn{2}{c}{2015} & \multicolumn{2}{c}{2014} & \multicolumn{2}{c}{2013} \\
& Rasio & Skor & Rasio & Skor & Rasio & Skor & Rasio & Skor \\
\hline
\end{tabular}

\section{Permodalan}

Rasio modal sendiri terhadap total asset

Rasio kecukupan modal (CAR)

\section{Kualitas Aktiva Produktif}

Rasio tingkat pembiayaan dan piutang bermasalah terhadap jumlah piutang dan pembiayaan Rasio portofolio pembiayaan beresiko

Rasio penyisihan penghapusan aktiva produktif

\section{Efisiensi}

Rasio biaya operasional pelayanan terhadap partisipasi bruto

Rasio aktiva tetap terhadap asset

Rasio efisiensi Pelayanan

\section{Likuiditas}

Rasio kas

Rasio pembiayaan terhadap dana yang diterima

\section{Kemandirian dan}

\section{pertumbuhan}

Rentabilitas asset

Rentabilitas modal sendiri

Rasio kemandirian operasional

Kesehatan KSPPS BMT Mitra

Mandiri per tahun

Katagori

Sumber : Data Sekunder KSPPS BMT Mitra Mandiri yang Diolah

$\begin{array}{rrrrrrrr}7,50 \% & 1,25 & 6,61 \% & 1,25 & 6,86 \% & 1,25 & 5,76 \% & 1,25 \\ 8,21 \% & 5,00 & 6,98 \% & 2,50 & 8,53 \% & 5,00 & 6,37 \% & 2,50 \\ & & & & & & & \\ 0,94 \% & 10,00 & 0,81 \% & 10,00 & 1,06 \% & 10,00 & 0,82 \% & 10,00 \\ & & & & & & & \\ 0,90 \% & 5,00 & 2,63 \% & 5,00 & 3,93 \% & 5,00 & 1,97 \% & 5,00 \\ 43,24 \% & 2,00 & 27,91 \% & 1,50 & 24,69 \% & 1,00 & 120,77 \% & 5,00\end{array}$

$\begin{array}{rrrrrrrr}35,00 \% & 4,00 & 34,26 \% & 4,00 & 30,99 \% & 4,00 & 34,12 \% & 4,00 \\ 6,21 \% & 4,00 & 6,52 \% & 4,00 & 2,22 \% & 4,00 & 2,16 \% & 4,00 \\ 5,15 \% & 0,50 & 4,66 \% & 0,50 & 4,25 \% & 0,50 & 3,13 \% & 0,50 \\ & & & & & & & \\ 18,10 \% & 5,00 & 16,05 \% & 5,00 & 31,01 \% & 10,00 & 25,10 \% & 7,50 \\ 92,85 \% & 3,75 & 105,93 \% & 5,00 & 100,09 \% & 5,00 & 102,11 \% & 5,00\end{array}$

$\begin{array}{rrrrrrrr}10,32 \% & 3,00 & 10,17 \% & 3,00 & 10,96 \% & 3,00 & 10,63 \% & 3,00 \\ 8,79 \% & 2,25 & 9,59 \% & 2,25 & 9,37 \% & 2,25 & 11,12 \% & 3,00 \\ 285,70 \% & 4,00 & 291,87 \% & 4,00 & 322,63 \% & 4,00 & 293,07 \% & 4,00 \\ & 49,75 & & 48,00 & & 55,00 & & 54,75\end{array}$

Sehat Sehat Sehat Sehat 
panjang yang dimiliki oleh KSPPS BMT Mitra Mandiri dari tahun 2014 sampai dengan tahun 2016. Peningkatan modal sendiri dari tahun 2013 -2016, tidak diimbangi dengan peningkatan pinjaman pihak luar maupun simpanan dari anggota. Menurut Yusuf (2016) untuk meningkatkan modal dengan mudah, koperasi harus mampu menumbuhkan kepercayaan penuh anggotanya dengan menciptakan nilai manfaat, transparansi dan keadilan. Langkah lain yang dapat diambil KSPPS yaitu menciptakan produk simpanan khusus yang dapat menarik minat anggotanya untuk menyimpan dananya di KSPPS atau meningkatkan prosentase cadangan modalnya (Raharjo dan Indriani, 2017).

Dengan demikian, seharusnya untuk dapat memperbaiki rasio ini, KSPPS BMT Mitra Mandiri harus menyeimbangkan modal sendiri dengan modal pinjaman melalui peningkatkan pinjaman dari luar. Cara ini adalah cara yang praktis dilakukan, akan tetapi cara ini menimbulkan biaya bagi hasil yang akan mengurangi pendapatan anggota. Menurut Bintoro \& Soekarto (2013) masuknya modal dari luar menunjukkan bahwa KSPPS memperoleh kepercayaan, tetapi karena menimbulkan pengurangan pendapatan bagi anggota, maka harus dilakukan dengan kehati-hatian. Cara lain yang dapat dilakukan KSPPS BMT Mitra Mandiri adalah memotivasi anggotanya untuk semakin banyak menyimpan dananya ke KSPPS dengan kreatif menciptakan inovasi produk simpanan yang menarik. Nilai maksimal rasio ini dapat dicapai KSPPS BMT Mitra Mandiri ketika jumlah modal sendiri terhadap total modal berada pada $20 \%-50 \%$.

\section{Rasio Kecukupan Modal}

Dari tabel 3 menunjukkan bahwa rata-rata dari tahun 2013-2016 mendapat nilai 100 dengan skor 3,00 dengan rasio $6,37 \% ; 8,53 \% ; 6,98 \% ; 8,21 \%$ secara berurutan. Rasio rata-rata yang diperoleh sebesar 7,52\% dengan skor rerata yang diperoleh yaitu 3,75. Artinya secara rerata, modal tertimbang KSPPS BMT Mitra Mandiri memiliki kualitas cukup sehat dalam mendukung adanya Aktiva Tertimbang Menurut Risiko (ATMR) yang dimiliki. Hasil Penelitian ini tidak sejalan dengan penelitian sebelumnya, yaitu penelitian yang dilakukan Raharjo dan Indriani (2017), Sukmana dan Mulyati (2015), Yusuf (2016).

Pada tahun 2014 dan 2016, KSPPS memiliki nilai kecukupan modal dalam katagori sehat, dengan skor maksimal sebesar 5. Dengan demikian, penge- lola KSPPS BMT Mitra Mandiri telah berhasil melakukan pengembangan usaha yang sehat, disis lain modal yang dimiliki KSPPS BMT Mitra Mandiri mampu menanggung kemungkinan adanya resiko kerugian yang timbul dalam batas-batas yang telah ditentukan. Faktor yang mempengaruhi keberhasilan KSPPS ini dalam mencapai rasio CAR yang maksimal adalah kenaikan modal inti dan modal pelengkap dari tahun ke tahun, sehingga peningkatan modal ini mampu mengantisipasi resiko kerugian yang kemungkinan timbul.

KSPPS memiliki bidang bisnis yang nyaris sama dengan perbankan syariah. Berdasarkan Surat Edaran Bank Indonesia No 7/53/DpbS/ 2005 yang diubah menjadi Surat Edaran Bank Indonesia No 8/10/DpbS/ 2006 menyebutkan adanya kewajiban bagi bank untuk menyediakan modal minimum sebesar $8 \%$ atas aset tertimbang, termasuk bank umum yang melaksanakan kegiatan usaha berdasar prinsip syariah. Bank dapat menjadi salah satu faktor penyebab baik atau buruknya kualitas kredit yang diberikan. Apabila dalam suatu pemberian kredit dilaksanakan dengan prinsip kehati-hatian, dan terhadap kredit yang telah diberikan tersebut dilakukan pengawasan dengan baik, maka kualitas kredit suatu Bank akan tetap terjaga dengan baik. Sebaliknya apabila pemberian kredit tidak dilakukan dengan baik, maka kualitas kredit suatu Bank akan dengan mudah menjadi buruk. Pengawasan dapat dilakukan semenjak pengajuan kredit hingga debitur penerima kredit (Maidalena, 2014). Prinsip kehatihatian dalam pemberian kredit dapat ditempuh Bank dengan cara melakukan seluruh ketentuan yang berlaku. Misalnya, dalam prosedur pemberian kredit, Bank harus memperhatikan seluruh tahapan prosedur yang berlaku, mulai dari permohonan kredit, analisis kredit, persetujuan kredit, pencairan kredit,sampai dengan pelunasan kembali kredit tersebut.

\section{Penilaian Aspek Kualitas Aktiva Produktif Rasio tingkat pembiayaan dan piutang bermasalah terhadap jumlah piutang dan pembiayaan}

Berdasarkan analisis yang telah dilakukan, menunjukkan bahwa rasio tingkat pembiayaan dan piutang bermasalah terhadap jumlah piutang dan pembiayaan selama tahun 2013-2016 memperoleh rasio diperoleh sebesar $0,82 \% ; 1,06 \% ; 0,81 \% ; 0,94 \%$ sehingga mendapat nilai 100 dengan skor 10,00 . Rasio rata-rata yang diperoleh sebesar $100 \%$ dengan skor 10,00 dan merupakan skor maksimal. Hasil ini 
sesuai dengan penelitian dari Sukmana dan Mulyati (2015) juga Afandi (2014).

Skor yang diperoleh KSPPS BMT Mitra Mandiri ini berarti bahwa KSPPS BMT Mitra Mandiri dalam aktivitas simpan pinjam kepada anggota pada tahun tersebut dapat dikatakan tinggi. Dengan kondisi ini diharapkan manajemen KSPPS BMT Mitra Mandiri mampu mempertahankannya.

\section{Rasio portofolio pembiayaan beresiko}

Berdasarkan analisis yang telah dilakukan, menunjukkan bahwa pada Rasio portofolio pembiayaan beresiko tahun 2013-2016 yaitu 1,97\%; 3,93; 2,63; 0,90. Dengan mendapatkan nilai maksimal yaitu 100 dengan rerata skor 5 yaitu skor maksimal dengan kriteria tidak beresiko. Hasil ini sesuai dengan hasil penelitian Raharjo dan Indriani (2017), Sukmana dan Mulyati (2015), Yusuf (2016).

Hal ini menujukkan KSPPS BMT Mitra Mandiri memiliki tingkat risiko pembiayaan beresiko yang rendah pada tahun 2013-2016. Kondisi ini menunjukkan bahwa manajemen KSPPS BMT Mitra Mandiri mampu memberikan jaminan keamanan kepada anggota yang melakukan transaksi pembiayaan di KSPPS. Harapannya adalah kondisi dapat terus dipertahankan oleh KSPPS BMT Mitra Mandiri.

\section{Rasio penyisihan penghapusan aktiva produktif}

Berdasarkan hasil analisis yang telah dilakukan, KSPPS BMT Mitra Mandiri memperoleh rasio cadangan risiko $120,77 \%-25 \%-28 \%$ - $43 \%$ secara berurutan pada tahun 2013-2016 sehingga diperoleh skor $5 ; 1 ; 1,5$ dan 2. Skor 5 merupakan maksimal skor. Hasil ini sejalan dengan penelitian yang telah dilakukan Yusuf (2016). Skor ini memiliki arti bahwa KSPPS memiliki cadangan yang diragukan sanggup menutup pinjaman bermasalah pada tahun tahun 2013.

Di tahun 2014, skor ini turun dratis, karena tidak adanya keseimbangan peningkatan nilai cadangan resiko dan pembiayaan yang dikeluarkan. Di tahun 2014 sampai dengan 2016, KSPPS BMT Mitra Mandiri berada dalam kriteria diragukan. Haisl ini seperti temuan dari Raharjo dan Indriani (2017). Jika dicermati lagi, dari tahun 2014 sampai dengan 2016, KSPPS BMT Mitra Mandiri telah berusaha memperbaiki kinerjanya, ditandai dengan peningkatan skor dari tahun 2014 ke tahun 2016.

Penilaian Aspek Efisiensi

Rasio Beban Operasi Anggota terhadap Partisipasi Bruto
Berdasarkan analisis yang telah dilakukan, menunjukkan bahwa pada tahun 2013-2016, peroleh rasio sebesar $34,12 \% ; 30,99 \% ; 34,26 \%$; 35\% secara berurutan, sehingga mendapat nilai 100 dengan skor 4,00. Rasio rata-rata yang diperoleh sebesar $8,24 \%$ dengan skor 4,00 dan merupakan skor maksimal. Hasil ini selaras dengan temuan Afandi (2014) dan Yusuf (2016).

Hal ini berarti bahwa KSPPS BMT Mitra Mandiri telah berhasil memberikan efisiensi pelayanan yang baik kepada para anggotanya dari penggunaan aset yang dimiliki. Partisipasi bruto yang tinggi menunjukkan bahwa kontribusi anggota terhadap koperasi juga tinggi dan meningkatkan perolehan SHU. Konsidi ini sesuai pendapat dari Yusuf (2016) yang menjelaskan bahwa untuk mencapai efisiensi maksimal, koperasi syariah harus mampu menyeimbangkan biaya yang dikeluarkan dengan pendapatan yang diperoleh, dimana hal ini dapat diperoleh melalui pengawasan yang ketat serta penyusunan anggaran yang akurat.

\section{Rasio aktiva tetap terhadap aset}

Berdasarkan analisis yang telah dilakukan menunjukkan bahwa pada tahun 2013-216 diperoleh rasio sebesar 2,16\%; 2,22\%; 6,52\%; 6,21 secara berurutan, sehingga mendapat nilai 100 dengan skor 4,00. Rasio aktiva tetap terhadap aset tahun tersebut memperoleh rasio rata-rata $4,27 \%$ dengan rerata skor diperoleh sebesar 4,00. Hal ini berarti KSPPS BMT Mitra Mandiri sudah efisien dalam menggunakan aktiva yang dimilikinya untuk berbelanja aktiva tetap. Hasil penelitian ini sesuai dengan temuan dari Afandi (2014), Yusuf (2016) dan Raharjo dan Indriani (2017).

\section{Rasio Efisiensi Pelayanan}

Berdasarkan analisis yang telah dilakukan, menunjukkan bahwa pada tahun 2013-2016 diperoleh rasio sebesar $3,13 \% ; 4,25 \% ; 4,66 \% ; 4,15 \%$ secara berurutan sehingga mendapat nilai 25 dengan skor 2,00. Rasio efisiensi pelayanan KSPPS BMT Mitra Mandiri selama tahun 2013-2016 memperoleh hasil rasio rata-rata $4,29 \%$ dengan rerata skor yaitu 0.5 . Semakin rendah rasio yang dihasilkan, maka semakin rendah skor yang diperoleh. Hal ini berarti bahwa KSPPS BMT Mitra Mandiri tergolong tidak baik dalam efisiensi pelayanan. Hasil ini sejalan dengan temuan Raharjo dan Indriani (2017).

Faktor yang mempengaruhi hal ini adalah jumlah honor dan gaji karyawan terlalu sedikit dibanding jumlah piutang dan pembiayaan KSPPS. 
Banyaknya cabang yang dimiliki KSPPS BMT Mitra Mandiri mengharuskan adanya jumlah karyawan yang besar dalam memberikan pelayanan kepada anggotanya. Peningkatan pembiayaan dari tahun 2013 sampai dengan tahun 2016 tidak diimbangi dengan peningkatan gaji karyawan. Menurut Yusuf (2016) untuk menyeimbangkan rasio ini sebaiknya KSPPS melakukan renumerasi dalam sistem penggajian dengan mempertimbangkan tingkat kebutuhan karyawan dan penerapan kerja yang sesuai dengan ketentuan pemerintah dan prinsip syariah. Dengan kondisi ini akan menimbulkan hubungan mutualisme antara koperasi dan karyawan. Dengan demikian, seharusnya KSPPS BMT Mitra Mandiri memperbaiki sistem kesejahteraan karyawannya agar dapat meningkatkan rasio efisiensi pelayanannya.

\section{Penilaian Aspek Likuiditas}

\section{Rasio Kas}

Berdasarkan analisis yang telah dilakukan menunjukkan bahwa rasio pada tahun 2013-2016 diperoleh rasio sebesar $25,10 \% ; 31,01 \% ; 16,05 \%$; $18,10 \%$ sehingga mendapat nilai 25 dengan skor 0,25 . Rasio kas memperoleh rata-rata $22,56 \%$ dengan rerata skor yang diperoleh yaitu 6,875 dan merupakan skor yang cukup likuid. Temuan ini sejalan dengan temuan dari Afandi (2014). Kondisi ini menunjukkan belum berhasilnya manajemen kas yang diterapkan KSPPS.

KSPPS BMT Mitra Mandiri sebaiknya menyeimbangkan kas dan bank dengan kewajiban lancarnya. Nilai kas dan bank dapat diperkecil dengan cara menyalurkan dana tersebut ke anggota dalam bentuk pinjaman. Dengan demikian, tidak banyak nilai uang di kas dan bank yang menganggur dan tidak produktif. Disisi lain manajemen kas KSPPS harus diperbaiki, sehingga optimal ketika anggota melakukan pengambilan dana di KSPPS.

\section{Rasio Pinjaman yang Diberikan terhadap Dana yang Diterima}

Berdasarkan analisis yang telah dilakukan menunjukkan bahwa pada tahun 2014-2016 diperoleh rasio sebesar 102,11\%; 100,09\%; 105,93; 92,85\% sehingga mendapat nilai 100 dengan skor 5,00. Rasio rata-rata selama tahun tersebut memperoleh hasil sebesar 100,24\% dengan skor rerata 4,68 dan merupakan skor maksimal. Semakin tinggi rasio yang dihasilkan, maka semakin rendah tingkat pinjaman bermasalahnya. Temuan ini sejalan dengan temuan Sukmana dan Mulyati (2015).
Hal ini berarti KSPPS BMT Mitra Mandiri tidak mengalami risiko pinjaman bermasalah dalam prosentase yang besar. Dalam perbankan, rasio ini dikenal sebagai Loan to Deposit Ratio (LDR). Menurut Islam (2012), ketika LDR menunjukan nilai yang lebih tinggi menunjukkan banyaknya sumber daya yang tersedia untuk kegiatan ekonomi, yang pada akhirnya akan menghasilkan lebih banyak sumber daya jika digunakan secara efisien. Adapun LDR yang rendah menunjukkan posisi likuiditas yang tinggi dengan timgkat resiko yang lebih rendah, tetapi mungkin berpotensi kurang menguntungkan karena sumber daya yang dimiliki tidak sepenuhnya dimanfaatkan untuk menghasilkan lebih banyak keuntungan. Dengan demikian, seharusnya KSPPS BMT Mitra Mandiri dapat mengoptimalkan dana yang ada untuk meningkatkan kesejahteraan anggotanya.

\section{Aspek Kemandirian dan Pertumbuhan \\ Rasio Rentabilitas Aset}

Berdasarkan analisis yang telah dilakukan, menunjukkan bahwa pada tahun 2013-2016 diperoleh rasio masing-masing sebesar 10,63\%; 10,96\%; $10,17 \% ; 10,32 \%$ sehingga mendapat nilai 100 dengan skor 3. Rasio selama tahun tersebut memperoleh hasil rasio rata-rata $10,51 \%$ dengan rerata skor yang diperoleh yaitu 3 dan merupakan skor tertinggi. Skor maksimal yang dapat diperoleh yaitu 3,00; dengan rasio lebih berar dari $10 \%$ berdasarkan peraturan penskoran. Hasil ini berbeda dengan penelitian terdahulu.

Semakin tinggi rasio yang diperoleh, maka semakin tinggi tingkat rentabilitasnya. Hal ini berarti rentabilitas aset KSPPS BMT Mitra Mandiri dalam kondisi yang sangat baik. KSPPS BMT Mitra Mandiri mampu meningkatkan perolehan SHU sebelum pajak dengan memaksimalkan pendapatan melalui partisipasi anggota dalam kegiatan simpan pinjam. Hendaknya KSPPS BMT Mitra Mandiri mampu mempertahankan kondisi ini.

\section{Rasio Rentabilitas Modal Sendiri}

Berdasarkan analisis yang telah dilakukan menunjukkan bahwa pada tahun 2014-2016 diperoleh rasio masing-masing sebesar $11,12 \%$; $9,37 \%$; 9,59\%; $8,79 \%$, sehingga mendapat nilai 81,25 dengan skor 2,43 dan skor tersebut merupakan skor cukup berdasarkan pedoman penskoran. Temuan ini sesuai temuan Raharjo dan Indriani (2017).

Hal ini berarti rentabilitas modal sendiri KSPPS BMT Mitra Mandiri dalam kondisi yang cukup baik. KSPPS BMT Mitra Mandiri mampu meningkatkan perolehan SHU bagian anggota dengan memaksi- 
malkan modal sendiri walaupun belum sepenuhnya. Kondisi ini sejalan dengan rasio permodalan, dimana masih rendahnya modal sendiri yang dimiliki oleh KSPPS BMT Mitra Mandiri. Hal lain yang dilakukan untuk memperbaiki skor ini adalah dengan menekan biaya bagi hasil dengan pihak luar. Hal ini senada dengan Raharjo dan Indriani (2017), yang menyatakan harus ada pengurangan pinjaman pihak ketiga supaya biaya bunga bank dapat terkurangi. Dengan kata lain, pengambilan pinjaman pihak luar dapat dilakukan dengan mengedepankan prinsip kehatihatian supaya SHU yang diperoleh tetap terus meningkat.

\section{Rasio Kemandirian dan Operasional Pelayanan}

Berdasarkan analisis yang telah dilakukan menunjukkan bahwa pada tahun 2013-2016 diperoleh rasio sebesar 293,07\%; 322,63\%; 291,875; $285,70 \%$ sehingga mendapat nilai 100 dengan skor 4,00. Rasio selama tahun tersebut memperoleh hasil rasio ratarata $298,31 \%$ dengan rerata skor yang diperoleh adalah 4,00 dan merupakan skor maksimal. Temuan ini sejalan dengan temuan Afandi (2014) dan Yusuf (2016).

Hasil ini menunjukkan bahwa beban usaha dan beban perkoperasian yang dikeluarkan oleh KSPPS BMT Mitra Mandiri sangat efisien dibandingkan dengan partisipasi neto yang tinggi, sehingga diperoleh kualitas yang maksimal. Hal ini berarti bahwa dalam perihal rasio kemandirian dan operasional pelayanan tergolong sangat baik.

Berdasarkan wawancara yang dilakukan, keberhasilan kemandirian KSPPS BMTMitra Mandiri mampu menarik anggota dengan melalui berbagai promo yang memikat, seperti program umroh murah, qurban sapi murah, tabungan dan talangan haji. Dalam mitra dan masyarakat, KSPPS ini melakukan berbagai event olah raga maupun sosial, sebagai upaya untuk mengembangkan pangsa pasarnya dan memperkuat anggotanya/nasabahnya.

\section{Penilaian Kesehatan}

Hasil penilaian terhadap tingkat kesehatan KSPPS BMT Mitra Mandiri pada tahun 2013 memperoleh nilai 50,75 dengan predikat koperasi sehat. Tahun 2014 nilai naik menjadi 55 dengan predikat koperasi sehat. Tahun 2015 nilai turun menjadi 48 dengan predikat koperasi sehat. Selanjutnya pada tahun 2016 nilai naik lagi yaitu 49,75 dengan predikat koperasi sehat. Dengan demikian dapat dikatakan bahwa tingkat kesehatan KSPPS BMT Mitra Mandiri dari tahun 2013-2016 berada pada kondisi konstan yaitu dengan predikat koperasi sehat. Hasil ini menunjukkan adanya usaha dari manajemen KSPPS BMT Mitra Mandiri untuk mempertahankan dan memperbaiki kinerjanya dalam rangka memberikan pelayanan yang baik kepada anggotanya.

\section{Kesimpulan}

Berdasarkan analisis yang telah dilakukan, maka kesimpulan yang dapat diambil, sebagai berikut: 1) Aspek permodalan KSPPS BMT Mitra Mandiri tahun 2013-2016 diperoleh rasio modal sendiri terhadap total aset dengan kategori tidak sehat, sedangkan rasio kecukupan modal sendiri dalam kategori cukup sehat. 2) Aspek aktiva produktif KSPPS BMT Mitra Mandiri periode 20132016 yang terdiri dari Rasio tingkat pembiayaan dan piutang bermasalah terhadap jumlah piutang dan pembiayaan dalam katagori lancar, rasio portofolio pembiayaan beresiko dalam katagori tidak beresiko, dan rasio penyisihan penghapusan aktiva produktif dalam katagori lancar. 3). Aspek efisiensi, KSPPS BMT Mitra Mandiri periode 2013- 2016 dari rasio beban operasi anggota terhadap partisipasi bruto dalam katagori efisien, rasio aktiva tetap terhadap asset dalam katagori baik, akan tetapi rasio efisiensi pelayanan dalam katagori tidak baik. 4) Aspek likuiditas KSPPS BMT Mitra Mandiri tahun 20132016,dari rasio kas dalam katagori cukup likuid, sedangkan rasio pembiayaan yang diberikan terhadap dana yang diterima menunjukkan katagori likuid. 5) Aspek kemandirian dan pertumbuhan KSPPS BMT Mitra Mandiri tahun 2013-2016, dari rasio rentabilitas aset menunjukkan katagori tinggi, skor rasio kemandirian operasional di katagori tinggi, sedangkan rasio skor rentabilitas modal sendiri berada di katagori cukup. 6). Hasil penilaian terhadap tingkat kesehatan KSPPS BMT Mitra Mandiri pada tahun 2013-2016 dikategorikan dengan predikat cukup sehat, karena memperoleh rerata skor sebesar 50,875.

Atas hasil tersebut disarankan bahwa KSPPS BMT Mitra Mandiri dapat mempertahankan kesehatan keuangannya, terlebih dapat meningkatkannya dengan mempertahankan faktor-faktor keberhasilan pencapaian nilai maksimal setiap komponen penilaian, dan dapat memperbaiki faktor-faktor kelemahan yang mengakibatkan penurunan skor penilaian kesehatan keuangan. Dengan demikian, pencapaian nilai kesehatan yang maksimal tentunya sebagai indikator keberhasilan KSPPS BMT Mitra Mandiri dalam mencapai kinerjanya dan pastinya akan berim- 
bas pada pelayanan yang maksimal kepada anggotanya. Penelitian selanjutnya diharapkan tidak hanya memfokuskan pada analisa kesehatan keuangan, tetapi juga analisa manajemen serta prinsip syariah, sehingga dapat diketahui nilai kesehatan KSPPS secara utuh.

\section{Ucapan Terimakasih}

Terima kasih kepada Direktorat Riset dan Pengabdian Masyarakat Kementrian Riset dan Teknologi dan Perguruan Tinggi, yang telah mendanai terlaksananya penelitian ini.

\section{Daftar Pustaka}

Afandi, F. (2014) Analisis Kinerja Keuangan untuk Mengukur Kesehatan Keuangan Koperasi KSU BMT Arafah Kecamatan Bancak Kabupaten Semarang, Among Makarti Vol. 7 No 13 Juli 2014.

Arikunto, S. (2013). Prosedur Penelitian: Suatu Pendekatan Praktik, Jakarta:Rineka Cipta.

Bintoro, M. H., \& Soekarto, S. T. (2013). Strategi Pengembangan Koperasi Jasa Keuangan Syariah dalam Pembiayaan Usaha Mikro di Kecamatan Tanjungsari, Sumedang. MANAJEMEN IKM: Jurnal Manajemen Pengembangan Industri Kecil Menengah, 8(1), 27-35.

Hoque, Z. (2003). Strategic Management Accounting: Consept, Processes and Issues, Pearson Education Australia $2^{\text {th }}$ Edition.

Inayati, T., Subroto, B., Fachan, A. \& Djazuli, A. (2014) Analyzing Islamic Micro Finance Performance with Economic Value Added (EVA): Learning from Baitul Wat Tamwil (BMT) Usaha Gabungan Terpadu Sidogiri Indonesia , Jurnal Business and Management Horizons Vol. 2, No. 2, p. 2937.

Maidalena. (2014). Analisis Faktor Non Performing Financing (NPF) pada Industri Perbankan Syariah. Jurnal Human Falah: Volume 1. No. 1 Januari-Juni 2014

Mulyadi. (2001). Sistem Perencanaan dan Pengendalian Manajemen: Sistem Pelipatganda Kinerja Perusahaan. Jakarta: Salemba Empat

Nornita, L. M. (2012). Analisis Tingkat Kesehatan Lembaga Keuangan Syariah:
Studi Pada Bmt Bina Ihsanul Fikri Tahun 2000-2011. Fakultas Syari'ah Dan Hukum Universitas Islam Negeri Sunan Kalijaga Yogyakarta.

Nurhayadi. (2015). Comprehensive Supervision for Operational Soundness of Sharia Financial Service Cooperatives, Jurnal Human Falah: Volume 2. No. 1 Januari Juni 2015 p 113-13.

Peraturan Deputi Bidang Pengawasan Kementerian Koperasi Dan Usaha Kecil Dan Menengah Republik Indonesia Nomor: 7 /Per/Dep.6/Iv/2016 tentang Pedoman Penilaian Kesehatan Koperasi Simpan Pinjam dan Pembiayaan Syariah dan Unit Simpan Pinjam dan Pembiayaan Syariah Koperasi.

Peraturan Menteri Koperasi Dan Usaha Kecil Dan Menengah Republik Indonesia Nomor 16 /Per/M.Kukm/IX/2015 tentang Pelaksanaan Kegiatan Usaha Simpan Pinjam dan Pembiayaan Syariah oleh Koperasi .

Peraturan Menteri Negara Koperasi Dan Usaha Kecil Dan Menengah Republik Indonesia Nomor : 35.3/Per/M.Kukm/X/2007 Tentang Pedoman Penilaian Kesehatan Koperasi Jasa Keuangan Syariah Dan Unit Jasa Keuangan Syariah Koperasi.

Raharjo, T. H. dan Indriani, H. (2017) Analisis Tingkat Kesehatan KSPPS BMT Bina Ummat Mandiri Kota Tegal Tahun 2016, Jurnal Bisnis Dan Manajemen (Jbima) Vol. 5, No. 1, Maret 2017 Hal. 61 - 79.

Soedarsa, Herry Gunawan dan Desty Natalia, (2016), Analisis Tingkat Kesehatan Koperasi Pada Koperasi Simpan Pinjam Di Kabupaten Tulang Bawang Barat. Jurnal Akuntansi dan Keuangan Vol. 7 No. 2 September 2016.

Sugiyarso, G. (2011). Akuntansi Koperasi: Sistem, Metode dan Analisis Laporan Keuangan, Yogyakarta: PT. Buku Seru.

Sukmana, A. A. dan Mulyati, S. (2015) Penilaian Kesehatan KJKS BMT Binamas, Jurnal Akuntansi dan Keuangan Islam Vol. 2., No 2 (2015), hal 125-14.

Syofyan, A. dan Ervina. (2017). Analisis Tingkat Kesehatan Koperasi Jasa Keuangan Syariah 
Jurnal Ilmiah Ekonomi Islam, 4(02), 2018, 115

Baitul Maal Wat Tamwil Dengan Metode Camel, Jurnal Maqdis: Jurnal Kajian Ekonomi Islam -Volume 2, Nomor 2, JuliDesember 2017, p 129-140.
Yusuf, B. (2016). Analisis Tingkat Keuangan Koperasi Syariah, Jurnal Bisnis dan Manajemen Vo. 6 No 1. 